\title{
Climate-Smart Milk
}

\begin{abstract}
Global average milk consumption per person now tops 100 kilograms a year. In the US and across much of Europe we put away well over double this average. Some 700 million tonnes is produced worldwide annually with the UK being a net exporter of milk products and boasting a dairy herd numbering almost two million cows. Cows are a major source of the powerful greenhouse gas methane. Each litre of fresh milk we purchase is responsible for the equivalent of 3 kilograms of greenhouse emissions - over half a kilogram per standard glass. Milk is one of the most wasted foods in the UK at 290,000 tonnes each year. Reduced wastage by households is therefore central to reducing milks carbon footprint. On farms, improved animal health can provide major emissions benefits, as can alterations in feed. Higher temperatures pose a risk to yields and may increase milk spoilage. Fodder quality is also likely to be reduced in a future climate while some major diseases like Blue Tongue could benefit from warming and changing rainfall patterns.
\end{abstract}

Keywords Methane $\bullet$ Spoilage $\bullet$ Fodder quality $\bullet$ Methanogens $\bullet$ Blue Tongue $\bullet$ Liver flukes $\bullet$ Agroforestry $\bullet$ Heat waves $\bullet$ Ruminants $\bullet$ Antibiotic resistance 
Milk is a must-have for most breakfasts. Whether drunk neat, added to tea and coffee, or consumed as butter, cream, yoghurt and cheese, the global average consumption per person now tops 100 kilograms of the stuff each year. In the US and across much of Europe we put away well over double this average, though the global king of the milk moustache is Finland at over 400 kilograms of milk per person per year (Fig 5.1).

The vast majority of what we consume is in some form of cow's milk, with around 700 million tonnes produced worldwide annually. It can be produced in a very wide range of climates as long as the cattle are kept well fed. As a result, most regions of the world are deemed to be self-sufficient [2], and the fresh milk consumed in a country is often produced there too.

The UK is no exception to this, being a net exporter of milk products and boasting a dairy herd numbering almost two million cows [3]. Milk drinking here was institutionalised in schools and nurseries across post-war Britain, with the provision of free milk to all children up to the age of five (designed to give them a boost in nutrition at a time when food supplies

\section{Per capita milk consumption, 2013}

Average per capita milk consumption, measured in kilograms per person per year. This includes the milk equivalents of dairy products made from milk ingredients, but excludes butter. Data is based on per capita food supply at the consumer level, but does not account for food waste at the consumer level.
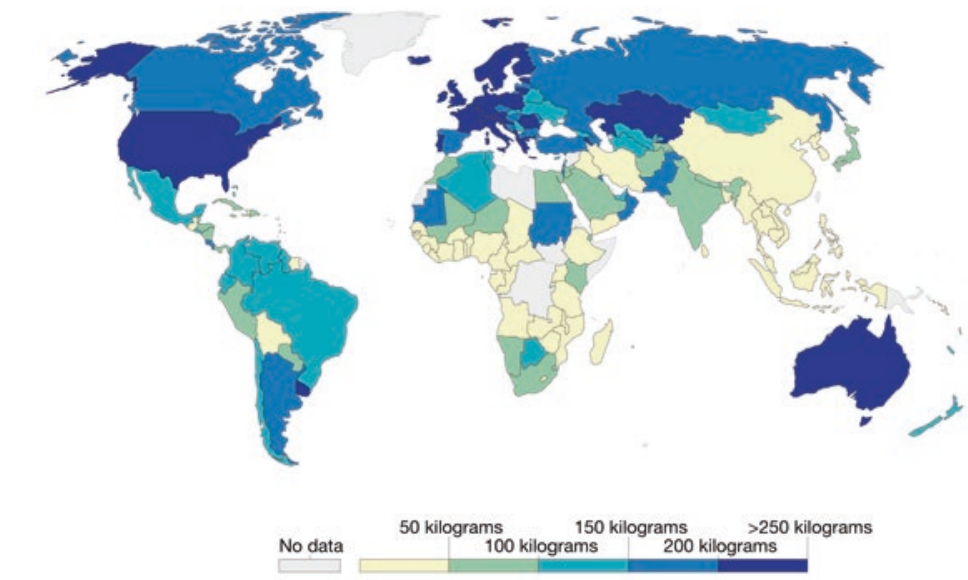

Fig. 5.1 Global milk consumption per capita in 2013 (Source: Hannah Ritchie, Our World in Data) [1]. Available at: https://ourworldindata.org/grapher/percapita-milk-consumption 
were low). This school milk provision continued for decades and was extended to older school children too. For many it is still a fond memory and one that set them on the road to a lifetime of milk drinking. Personally, I hated it.

In the Britain of the 1970s cut backs had already meant that free milk supplies were reduced. Unfortunately for me, our small primary school in rural Lincolnshire still got its daily supply. Each morning a crate of small bottles with thin foil lids was delivered to outside the Headmaster's entrance. On cold days it froze-the milk pushing up the lids to leave short white lollies. On warm days it baked and was pecked at by wild birds. Whether frozen, pecked or near-rancid, each child was given a bottle and made to drink it. I was a hungry boy and constantly vying with my brothers for food at home. Yet a few fraught episodes of being forced to drink the warm, borderline-rancid milk of school put me off it for life.

As an estimated nine out of ten people in Britain still regularly consume fresh milk [4], most would seem to have avoided such hang-ups. British consumers bought some five and a half billion litres of fresh milk in 2017, at a cost of over $£ 3$ billion [5]. Milk remains a big global foodstuff. Unfortunately for our climate, it can also have a very big carbon footprint.

Cows are a major source of the powerful greenhouse gas methane. Most of this methane is formed in a cow's rumen (its first stomach) by microbes involved in the breakdown and fermentation of grass and other feeds. The bulk of it is then belched back into the atmosphere, with a single Daisy, the dairy cow, able to produce hundreds of litres of methane in a single day [6] (over 100 kilograms over the course of a year [7]). More emissions then arise from cattle manure and urine, from land use change and cattle feed production, and from the collection, processing and distribution of milk itself [8].

The result is that each litre of fresh milk we purchase is responsible for the equivalent of 3 kilograms of greenhouse emissions [9] -that's over half a kilogram per standard glass of the white stuff $[8,10]$. For most consumers, their direct role in this hefty footprint might seem minor. Yes, there's the transport of milk from store to home, and the electricity we use to power our refrigerators, but these amount to less than a tenth of the total [8]. Where we can really dent the lifecycle emissions of milk (and in this case it's a very deep dent) is through less waste.

In the US, consumers waste around one-fifth of the milk they buy, with about 12 per cent also being wasted by retailers [8]. Likewise, milk is one of our biggest throw-away foods in the UK-290,000 tonnes each year at 
a cost to households of $£ 290$ million [11]. The reasons for such huge amounts of avoidable milk wastage centre on it not being used in time, too much being served and personal preference (fussy eaters like me refusing it). Consumers giving the milk they buy the best possible chance of being used is at the heart of tackling this waste [12]. This includes smaller, more frequent milk shopping, keeping it cold and knowing what you need-checking how much is in the fridge and its use-by date for instance [13].

That ripple effect of consumer action on food waste, then reducing emissions all the way back up through the supply chain, could be enormous for milk. Halving avoidable milk waste by UK households would deliver a cut equivalent to over 400,000 tonnes of emissions each year. For the US, comprehensively tackling milk waste by stores and households (cutting waste to just 3 and 5 per cent respectively) would together slice a quarter off the life cycle emissions of milk there [8] and deliver a staggering 8 million tonne reduction in the greenhouse gas emissions of the US dairy industry.

As climate change intensifies the importance of a resilient supply chain for high emission-short lifetime foods becomes even more important. There's a potential double-whammy in that the shelf lives of highly perishable foods like milk are themselves at risk-rising temperatures will increase food spoilage unless refrigeration is able to keep up. These cold-chain climate impacts have so far mainly been looked at in terms of food poisoning, such as accelerated growth of Salmonella on meat in warmer conditions [14]. For milk, the extra load put on refrigeration to keep it fresh in a future climate may well increase electricity demand, but any extra emissions from this would be dwarfed by the savings made through reduced spoilage and waste.

For many households in the developed world this may simply involve upgrading to a more energy-efficient fridge and making sure the food is not left out on worktops for too long. Further up the supply chain, more intense heat waves and the potential for transport delays due to floods will require everyone from farmers and processors to distributors and retailers to look at whether extra refrigeration, storage capacity and back-up power generation are needed [14]. 
Some manufacturers are trying to extend the lifetime of milk products using new technology, such as addition of bacterial strains that slow fungal growth and spoilage [15]. Longer-life milk is nothing new [16], with the use of ultra-high temperature (UHT) treatment having been around since the 1960s. This heat sterilisation means that, unopened, it can last without refrigeration for over six months. Condensed and sweetened milk has similar life-extending properties, usually coming in cans and often used instead of cream on deserts. As such, more uptake of these long-life milks could give more climate resilience to supplies and slash spoilage rates. A major downside to these types of milk is their distinctive 'cooked' taste.

My own uncle Bern loved the stuff, with no trip to the beach complete without a can of condensed Carnation milk to pour into his super-strong tea. Yet for those of us already unconvinced by the joys of fresh milk, this sweet and slightly brown-coloured stuff was horrible. As with so many foods, long-life milk is an acquired taste. It remains very popular in France, Spain and Italy where higher temperatures make it especially useful, while in the colder climes of Britain and Scandinavia fresh milk is preferred. For Uncle Bern, a pre-war childhood without fridges and an army career in the heat of North Africa guaranteed his life-long love for the dubious pleasures of condensed milk.

For most dairy farmers, preventing milk spoilage relies on strategies like good cattle husbandry, clean equipment and well-maintained chilling and storage systems - failing refrigeration can be a big source of milk spoilage insurance claims [17]. In less developed nations, limited access to refrigeration technology and reliable power supplies increases the risk of milk spoilage where temperatures soar or transport links are cut [18].

The sometimes-treacherous journey of milk from cow to our breakfast table is clearly one that could be made still more fraught by climate change. To date the supply chain risks of extreme weather have had relatively little attention worldwide. Instead, it is the very beginning of our milk's journey that has grabbed the most headlines and attracted the most research: the cows themselves.

Cows, like humans, don't like it too hot. If the temperature begins to push up into the high 20s Celsius (80s Fahrenheit) then heat stress impacts may start to show. First the cow becomes lethargic and sweaty, her breaths becoming shallower and faster. As temperatures move into the 30 s Celsius she may start to pant and her production of milk plummet. Without relief from the heat she may die. 
Modern dairy cows tend to be more susceptible to heat stress, as their high feed intakes, sizes and growth rates mean they generate more body heat [19]. Heat stress can also lead to a weakened immune system and the spread of diseases like mastitis [20]. Historically these kinds of hot weather impacts were only a big problem for cows in warm and tropical climates, but increasing temperatures at higher latitudes - including the US, Canada and Europe-have increased the risks to cattle there too [21].

Even where heat stress is relatively mild it can mean big reductions in milk production, and so major losses for farmers [22]. In the US alone it is estimated to cost the dairy industry $\$ 900$ million a year through reduced milk and calves, and increased culling. Production losses and increased mortality rates caused by high temperatures have been documented in many US states over the last decade [23]. In the summer of 2017, it was California-the biggest milk-producing state in the country-that showed just how damaging extreme heat can be.

In late June that year, temperatures began to rise quickly and hit the mid-30s Celsius (110 Fahrenheit). Milk production in the worst affected regions slumped by a fifth and an estimated 4,000 cattle died [24]. Without adaptation, climate change will make such impacts more frequent, more widespread and more severe. It is predicted that excessive heat and humidity could cost the US over $\$ 2$ billion a year by the end of the century if no action is taken. Hot, southern states like Florida may lose as much as a quarter of their milk production [25].

Over in Europe a similar trend of northward-creeping heat stress risk is emerging. The devastating heat wave of 2003 hit both humans and livestock hard, with 4,000 extra cattle deaths per week reported [26]. Subsequent heat waves in 2006 and in 2017 (the aptly-named 'Lucifer' heat wave) again took their toll on Europe's livestock and milk production [27].

For much of the twentieth century heat stress was a non-issue for most UK dairy herds; between 1973 and 2012 the average farm saw just 1 day each year where temperature and humidity climbed to a level where mild heat stress might occur [28]. The heat waves of the new millennium changed all that. Across the Midlands and the south of England, dairy cows typically experienced five days of heat stress-inducing conditions in the hot summers of 2003 and 2006. Milk yields from some herds were markedly reduced for a time, but these events served mostly as a warning of what the future may hold. Based on projected climate change in the UK 
[29], dairy herds in the south could be enduring an average of 30 to 40 days of such heat stress conditions each year by the end of this century.

To date, a far more familiar severe weather risk for dairy farmers in the $\mathrm{UK}$ is that of heavy rainfall and flooding. Waterlogged soils may make pasture land less productive and much more vulnerable to damage by grazing. In very wet years farmers are forced to keep their herds indoors for longer, meaning more reliance on cattle feed. Availability and quality of forage and feed itself can also suffer in really wet years (like those of 2012 and 2013), with higher costs and lower milk yields as a result [30]. Indeed, in many areas of the world there is a risk that future climate change impacts combined with a carbon dioxide-enriched atmosphere will mean big reductions in the quality of forage [31].

Along with the wetter winters and more extreme rainfall events may come the less visible but far more dangerous threat of disease. Dairy cows are valuable animals and farmers will try all they can to keep them well. Despite precautions, diseases like Foot and Mouth have devastated herds in recent years [32]. In 2007, discovery of Blue Tongue in British livestock again caused widespread concern [33]. This viral disease is spread by midges and had emerged in North Western Europe the previous year. It is spread most rapidly in warm and wet conditions, with its 2006 outbreak being attributed to the warming that has occurred in this region over the past 50 years [34].

As climate changes, so the distribution of disease vectors like midges will also change. Increasing risks of Blue Tongue are now predicted across most of Europe, with a warming climate meaning its range may expand across the US, western Russia and central Africa too [35]. The strict quarantine, livestock tracking and monitoring regime now in place in the UK [36] has so far helped to lower the risk of outbreaks of such non-endemic diseases. For some already-established cattle diseases and parasites, however, climate change could make existing problems a whole lot worse.

Liver flukes are flat parasitic worms that mainly affect cattle and sheep. Even a light infection can damage liver function and reduce productivitya heavy infection can kill the host animal. In the UK these parasites rely on a life cycle that starts off with eggs produced by the adult flukes in a cow's liver being excreted along with manure. If temperatures are high enough (over 10 degrees Celsius) the eggs develop quickly and produce the first microscopic mobile stage of the parasite. These then search out and infect the water snails common to many wet, low-lying grasslands. Within the snails the parasites grow and multiply fast (the warmer it is the faster they develop). After around 6 weeks the second mobile stage is released and 
these spread through the vegetation where they become infective cysts waiting for the next passing cow or sheep to chomp down on them [37].

As Britain has experienced warmer conditions and more flooding of grasslands, so the liver fluke parasites and their water snail vectors have flourished. More intense summer droughts have the potential to limit them in some areas in the future, but a trend of higher temperatures and more extreme rainfall risks enhancing the spread and impact of liver flukes across the UK $[38,39]$.

As a rule of thumb, where the welfare of dairy cows goes up greenhouse gas emissions come down. This certainly applies for adaptation to increasing heat - the majority of those livestock farmers in California who faced the wilting summer heat of 2017 have already put in place plans to protect their cows.

Many introduced shading in feeding, drinking and corral areas to give cows plenty of opportunities to seek respite from the sun when they need it [40]. Others use water sprayers and misters-as long as water supplies allow it - to cool the cows by evaporation. Some farms even employ large fans in the holding areas outside milking parlours, to keep air moving and temperatures down.

For those UK dairy farmers facing heat waves, similar sorts of cooling strategies could be the way forward. Here in Britain though, cattle are more often grazed on large areas of pasture during summer, and so may only come into more enclosed areas for milking times. At the milking parlour and its surrounds, providing shade, water sprays and fans can again reduce heat stress risks.

Proper refrigeration of the collected milk is also at risk with higher temperatures. Here, heat exchangers (that pre-cool the milk before refrigeration), and heat recovery units (that then collect the heat and use it for water heating), can radically reduce farm energy use and so greenhouse gas emissions [41].

Out in the fields there is often an opportunity to use the natural shading and shelter provided by trees to increase hot weather resilience-dairy cows given such shaded areas have shown reduced panting and heat stress symptoms [42]. Though, as we saw with Assam's tea gardens, the integration of trees with agriculture (agroforestry) is most commonly associated with growing crops, trees are a successful part of livestock systems around 
the world too [43]. Tree shelterbelts around fields can reduce the impacts of extreme weather events, including storms, intense rainfall, and extremes of heat and cold [44]. For areas of intensive agriculture they also represent an important opportunity to sequester more carbon dioxide from the atmosphere without having to lose productive farmland [45]. Some farmers have extended the benefits of livestock agroforestry to include extra forage for the animals, a source of biofuel for energy generation, and even as a natural filter for pollutants - the trees can help reduce nitrate leaching to drainage streams and capture ammonia emissions to the atmosphere $[46,47]$.

Just as heat wave warnings are now widely used to reduce risks to human health, so such warnings can help livestock farmers get plans in place to protect their herds. Reducing the numbers of cows held in confined spaces like milking parlours can be a good way to allow heat to disperse more easily. Likewise, providing additional drinking water supplies and shifting feeding times, so that cows are not all feeding during the hottest parts of the day, will cut heat stress risks. Even the cattle feed itself can be modified to make it more energy-dense and so reduce how much extra body heat is produced as it is digested [48]. In fact, changing what cows eat has a peculiar strand of food and climate change science all of its own.

Excess production of methane in the rumens of dairy cows is bad both for our climate and for dairy farmers. The microbes that produce the methane-methanogens-make use of the carbon dioxide and hydrogen generated as feed is fermented and digested. With harder-to-breakdown food, such as straw, more hydrogen is generated and so methane emissions tend to increase [49]. Providing dairy cows with higher quality feeds and forages can therefore mean less of the food is converted into methane and more of it into milk.

Scores of different feed and forage types have been assessed in terms of the methane penalties they incur [50]. Improving feed quality remains one of the standout strategies in efforts to boost production and reduce the carbon footprint of livestock. Yet, many farmers either do not have access to better feeds or their cattle range far and wide, making controlling what they eat near-impossible [51].

For those dairy farmers with closer control of the diet of their herds, and access to the latest feed mixes, there are some extra weapons in the methane-targeting armoury available [52]. While higher quality feeds shift digestion away from the hydrogen production the methanogens rely on, a 
host of feed additives can also be used to divert the hydrogen supply or even to target the methane-producing microbes themselves [53].

Australia is arguably the world leader in assessing exactly what might work best - their huge cattle and sheep populations mean livestock methane gets a lot of attention. The impacts of adding everything from tea, garlic and seaweed extracts [54], to cinnamon, curry spice and oregano have been examined over the years [55]. Many of these natural extracts work by directly inhibiting the methanogens. Others, like nitrate and sulphate additives, work by competing with the methanogens for any available hydrogen in the cow's rumen [56].

The results can be impressive-cuts in methane of over three-quarters have been reported in lab experiments [57]. They may also be short-lived. With prolonged exposure, the methane-producing microbes often become resistant to the effects of the additives. Too much use of nitrate additives can even prove toxic for the cows themselves [56]. The current frontrunner as an additive that increases productivity, cuts emissions and boosts climate resilience-the holy climate-smart trinity-is not an exotic curry spice or a rare algal extract: it is fat [58].

Fats, especially those rich in fatty acids like sunflower oil, are able to reduce methane $[59,60]$ and the amount of heat generated during digestion [61]. These dietary fats can be derived from many natural sources, including algae. They also avoid many of the public health issues associated with artificial methanogen inhibitors like antibiotics-an antibiotic called monensin is widely used in livestock feed to boost growth and cut methane emissions, but is banned in Europe due to concerns around the spread of antibiotic resistance [62].

Where antibiotics have a less controversial role in delivering climatesmart milk is in fighting disease. Together with improved veterinary care and animal health extension services, access to livestock medicines can vastly increase resilience to diseases and parasites that would otherwise attack cattle $[51,63]$.

For dairy farmers in the UK there are now vaccines available to help control the midge-borne Blue Tongue virus, as well as regular warnings about new outbreak risks and tight livestock movement restrictions wherever infection is confirmed [64]. The march of parasites like the liver fluke has been slowed by the use of flukicide drugs that kill the parasites while they are inside the host animal [65]. Yet with more drug use has come more drug resistance. New vaccines may again hold the solution, giving protection in areas where drug resistance is already established and provid- 
ing a longer-term defence for dairy farmers as liver flukes spread into new areas.

So, a healthy and happy cow is usually a more climate-resilient and lower-emissions cow. Even the happiest cows have a limit to the amount of milk they can produce though, and some breeds produce a lot more than others. For the carbon footprint of our breakfast milk, this is crucial.

In the push for bigger milk yields, dairy livestock have undergone intensive selection to emphasise sought-after traits. In just 60 years, genetic selection and improved management of North America dairy cows has quadrupled milk yields and halved the methane emissions of each litre of milk produced [60].

British herds are now dominated by the black and white HolsteinFriesian cow-a cross between the milk super-breed of Holstein imported from the US and Canada, and the fast-breeding Friesian cow that was the mainstay of UK dairy farming up until the 1980s. Holsteins are able to produce over 7 tonnes of milk a year (compared to around 6 tonnes per year for a Friesian) [66], so breeding cows that are all or mostly from Holstein stock makes sense for increasing milk yields. The downside is that more milk production may come at the cost of other desirable traits, like high fertility. The same large size and fast metabolism of Holstein cows that allows them to produce so much milk can also make them more susceptible to overheating and so more vulnerable to heat stress.

Further selection for and introduction of genetic traits [67]-like heat tolerance, higher yields or disease resistance-all have the potential to deliver climate-smart milk [60]. The real challenge is in finding the combination that works best for the specific locations and local circumstances of different dairy farms in a rapidly changing climate.

Beyond cow welfare and genetics, climate-smart milk relies on the whole dairy production system. If a new wonder feed wipes out livestock methane, but generates even bigger greenhouse gas emissions through its own production, then the climate benefit is lost. All cereals and crops have carbon footprints, so if they are then used to feed cattle this is added to the life cycle emissions of the milk we eventually drink [68]. In most cases though, cuts in dairy cow methane from improved feed will still outweigh the emissions from the feed itself. For many rangeland cows in the developing world the food they forage is wild-grown and inedible to humans. These browsing herds are effectively creating milk from 'zero carbon' feed, but often with hefty methane emissions in between thorny bush and milk churn, and so a big overall carbon footprint. 
Cow manure is itself a globally important source of methane, while both it and cow urine are rich in nitrogen and so contribute to emissions of the powerful greenhouse gas nitrous oxide too [52]. For dairy farmers, improved manure and urine management can turn this animal waste burden into a climate-smart blessing. In areas where cows congregate (e.g. in cattle sheds and outside milking parlours) the waste can be collected. This avoids the risk of it being washed into drainage waters by heavy rain or emitting large amounts of ammonia to the air on hot days. The collected waste is then a valuable feedstock for anaerobic digestion-the deliberate production and capture of methane for use as an energy source. Many farms already do this, using the biogas to heat buildings, generate electricity, or even to pump into the wider gas supply network [69]. The residues from the anaerobic digester then make an excellent soil improver to apply back on the fields and substitute for artificial fertilisers.

Even where anaerobic digestion is not an option, separating the manure and urine into covered storage often reduces air and water pollution problems. Methane will still be produced though, and aerating the manure, reducing storage times or even destroying the methane by flaring, have all been suggested as ways of reducing its climate impact [52]. Cow diet can affect these waste emissions too. Ironically, the same nitrate supplements that inhibit gut methanogens may boost nitrous oxide production in the cow's manure and urine-potentially just swapping the climate change penalty of milk from one place and gas to another.

The final big opportunities for climate-smart milk on the farm come in the way manures and fertilisers are applied, and the ways the cows use their fields. Getting the timing and amounts of manure and fertiliser right maximises how much of the nitrogen it contains is used by the grass or crops, and so minimises losses to air and water. For cow behaviour, keeping them away from waterlogged areas and streams, regularly moving feeders and drinkers about, and placing field gates at the top of slopes (where it's usually drier) can all help to reduce the compaction and 'poaching' of soils, and so the pollution and greenhouse gas emissions that result.

Globally, the challenge of realising such climate-smart milk remains a daunting one. Through heat stress and disease, reduced food supply and quality, climate change is already damaging production and pushing up the emissions of the milk we consume. In the UK we are blessed with expert dairy farmers with access to many of the feed mixes, medicines, technologies and animal breeding programmes needed to deliver high 
milk yields that are both climate resilient and low carbon. Large parts of the developing world have none of this [68].

New programmes, such as those supported by the World Bank are starting to change things. In Burkina Faso, many farmers are already employing small biodigesters that produce methane from manure for home cooking. The switch from charcoal and wood fuel to biogas reduces deforestation and improves air quality. Applying the nutrient-rich residues to fields then helps to boost yields and improve water retention of the soils_-vital as rainfall becomes less predictable. With financial help from 'carbon credits' gained by reducing greenhouse gas emissions, Burkina Faso's President is now aiming for 40,000 households to be using these biodigesters by 2020 [70].

Elsewhere, provision of research, extension services and opportunities to share good practice is helping to identify precisely which climate-smart milk strategies could be most feasible for specific situations. Large, intensive, Western-style dairy farming might look like a good goal on paper, but in reality this model risks distorting labour markets and damaging community cohesion if applied universally [51]. As ever, context-specific climate-smart solutions trump any amount of misplaced shiny technology.

\section{REFERENCES}

1. Ritchie, H. Global milk consumption per capita, 2013. Ourworldindata.org. https://ourworldindata.org/grapher/per-capita-milk-consumption (2018).

2. IDF. The World Dairy Situation 2016. Bulletin of the International Dairy Federation 485. https://www.idfa.org/docs/default-source/d-news/worlddairy-situationsample.pdf (2016).

3. AHDB. UK cow numbers. AHDB Dairy. https://dairy.ahdb.org.uk/marketinformation/farming-data /cow-numbers/uk-cow-numbers/\#. XOqSEy2ZPUo (2018).

4. DairyUK. The UK Dairy Industry. https://www.dairyuk.org/the-uk-dairyindustry/ (2018).

5. AHDB. Milk and Cream Market. https://dairy.ahdb.org.uk/market-information/dairy-sales-consumption/liquid-milk-market/\#.XOqSSy2ZPUo (2018).

6. Adam, D. How much brown cow? Nature. https://www.nature.com/ news/1998/000907/full/news000907-6.html (2000).

7. Dong, H., Mangino, J., McAllister, T. \& Have, D. Emissions from livestock and manure management. 2006 IPCC Guidelines for National Greenhouse Gas Inventories (2006). 
8. Thoma, G. et al. Greenhouse gas emissions from milk production and consumption in the United States: A cradle-to-grave life cycle assessment circa 2008. Int. Dairy J. 31, S3-S14 (2013).

9. Poore, J. \& Nemecek, T. Reducing food's environmental impacts through producers and consumers. Science 360, 987-992 (2018).

10. Tesco. Product Carbon Footprint summary. https://www.tescoplc.com/ assets/files/cms/Tesco_Product_Carbon_Footprints_Summary(1).pdf (2012).

11. WRAP. Household food and drink waste in the United Kingdom 2012. Waste and Resource Action Programme. http://www.wrap.org.uk/sites/files/wrap/ hhfdw-2012-main.pdf.pdf (2013).

12. WRAP. Preventing household dairy waste. WRAP Information SheetCourtauld Commitment 2. http://www.wrap.org.uk/sites/files/wrap/ Information sheet dairy_approved 1211 10_.pdf (2010).

13. WRAP. The milk model: Simulating food waste in the home. WRAP Final Report. http://www.wrap.org.uk/sites/files/wrap/Milk Model report.pdf (2013).

14. James, S. \& James, C. The food cold-chain and climate change. Food Res. Int. 43, 1944-1956 (2010).

15. Westergaard-Kabelmann, T. \& Olsen, M. D. Reducing food waste and losses in the fresh dairy supply chain. Chr. Hansen Impact Study. QBis Consulting. https://www.chr-hansen.com/_/media/203cf0800674489ab66c5acb666e 923d.pdf (2016).

16. Rysstad, G. \& Kolstad, J. Extended shelf life milk-Advances in technology. Int. J. Dairy Technol. 59, 85-96 (2006).

17. FMG. Milk Contamination and Spoilage. FMG Risk Advice Guide. https:// www.fmg.co.nz/globalassets/advice/fmgs-milk-contamination-risk-adviceguide_single.pdf (2015).

18. Liddiard, R., Gowreesunker, B. L., Spataru, C., Tomei, J. \& Huebner, G. The vulnerability of refrigerated food to unstable power supplies. Energy Procedia 123, 196-203 (2017).

19. Fidler, A. P. \& VanDevender, K. Heat Stress in Dairy Cattle. University of Arkansas Extension FSA3040. https://www.uaex.edu/publications/pdf/fsa3040.pdf.

20. AHDB. Heat Stress in Cattle. https://dairy.ahdb.org.uk/technical-information/ animal-health-welfare/mastitis/working-arena-prevention-of-infection/ housing/heat-stress-in-dairycattle/\#.XOqSdC2ZPUo (2018).

21. Polsky, L. \& von Keyserlingk, M. A. Invited review: Effects of heat stress on dairy cattle welfare. J. Dairy Sci. 100, 8645-8657 (2017).

22. St-Pierre, N., Cobanov, B. \& Schnitkey, G. Economic losses from heat stress by US livestock industries1. J. Dairy Sci. 86, E52-E77 (2003). 
23. Bishop-Williams, K. E., Berke, O., Pearl, D. L., Hand, K. \& Kelton, D. F. Heat stress related dairy cow mortality during heat waves and control periods in rural Southern Ontario from 2010-2012. BMC Vet. Res. 11, 291 (2015).

24. CBS. Cow carcasses pile up in California as heat wave causes mass death. CBS News. https://www.cbsnews.com/news/cow-carcasses-pile-up-in-californiaas-heat-wave-causes-mass-death/ (2017).

25. Mauger, G., Bauman, Y., Nennich, T. \& Salathé, E. Impacts of climate change on milk production in the United States. Prof. Geogr. 67, 121-131 (2015).

26. Morignat, E. et al. Assessment of the impact of the 2003 and 2006 heat waves on cattle mortality in France. PLoS One 9, e93176 (2014).

27. Henley, J. Extreme heat warnings issued in Europe as temperatures pass 40C. The Guardian. https://www.theguardian.com/world/2017/aug/04/ extreme-heat-warnings-issued-europe-temperatures-pass-40c (2017).

28. Dunn, R. J., Mead, N. E., Willett, K. M. \& Parker, D. E. Analysis of heat stress in UK dairy cattle and impact on milk yields. Environ. Res. Lett. 9, 064006 (2014).

29. Carbonbrief. Mapped: How every part of the world has warmed-And could continue to warm. Carbonbrief.org. https://www.carbonbrief.org/mappedhow-every-part-of-the-world-has-warmed-and-could-continue-to-warm (2018).

30. Morris, J. Weather spells hard times for UK dairy farmers. BBC Online. https://www.bbc.co.uk/news/uk-england-devon-20532875 (2012).

31. Dumont, B. et al. A meta-analysis of climate change effects on forage quality in grasslands: Specificities of mountain and Mediterranean areas. Grass Forage Sci. 70, 239-254 (2015).

32. Bates, C. When foot-and-mouth disease stopped the UK in its tracks. $B B C$ Online. https://www.bbc.co.uk/news/magazine-35581830 (2016).

33. BBC. Bluetongue declared an outbreak. BBC Online. http://news.bbc. co.uk/l/hi/uk/7018205.stm (2007).

34. Guis, H. et al. Modelling the effects of past and future climate on the risk of bluetongue emergence in Europe. J. R. Soc. Interface 9, 339-350 (2011).

35. Samy, A. M. \& Peterson, A. T. Climate change influences on the global potential distribution of bluetongue virus. PLoS One 11, e0150489 (2016).

36. DEFRA. Beef Cattle and Dairy Cows: Health Regulations. Department for Environment, Food \& Rural Affairs, UK. https://www.gov.uk/guidance/ cattle-health (2012).

37. AHDB. Sustainable Worm Control Strategies for Cattle. AHDB Dairy. https:// dairy.ahdb.org.uk/non_umbraco/download.aspx?media=16159 (2013).

38. Gale, P., Drew, T., Phipps, L., David, G. \& Wooldridge, M. The effect of climate change on the occurrence and prevalence of livestock diseases in Great Britain: A review. J. Appl. Microbiol. 106, 1409-1423 (2009). 
39. Fox, N. J. et al. Predicting impacts of climate change on Fasciola hepatica risk. PLoS One 6, el6126 (2011).

40. Tresoldi, G., Schütz, K. \& Tucker, C. Cow cooling on commercial drylot dairies: A description of 10 farms in California. California Agri. 71, 249-255 (2017).

41. FCCT. Energy efficiency advice for dairy farmers. Farmcarbontoolkit.org.uk. https://farmcarbontoolkit.org.uk/toolkit/energy-efficiency-advice-dairyfarmers (2018).

42. Schütz, K., Cox, N. \& Tucker, C. A field study of the behavioral and physiological effects of varying amounts of shade for lactating cows at pasture. J. Dairy Sci. 97, 3599-3605 (2014).

43. Dawson, I. K. et al. Agroforestry, Livestock, Fodder Production and Climate Change Adaptation and Mitigation in East Africa: Issues and Options (World Agroforestry Center, Nairobi, Kenya, 2014).

44. Smith, J., Zaralis, K., Gerrard, C. \& Padel, S. Agroforestry for livestock systems. SOLID Farmer Handbook: Technical Note 12. https://www.agricology. co.uk/resources/agroforestry-livestock-systems (2016).

45. Feliciano, D., Ledo, A., Hillier, J. \& Nayak, D. R. Which agroforestry options give the greatest soil and above ground carbon benefits in different world regions? Agri. Ecosyst. Environ. 254, 117-129 (2018).

46. Bealey, W. et al. The potential for tree planting strategies to reduce local and regional ecosystem impacts of agricultural ammonia emissions. J. Environ. Manag. 165, 106-116 (2016).

47. Wilson, M. \& Lovell, S. Agroforestry-The next step in sustainable and resilient agriculture. Sustainability 8, 574 (2016).

48. Thomas, C. Seven Practical Heat Stress Abatement Strategies. Michigan State University Extension. https://www.canr.msu.edu/news/seven_practical_ heat_stress_abatement_strategies (2012).

49. Yáñez-Ruiz, D. R. et al. Feeding Strategies to Reduce Methane and Ammonia Emissions. EIP-AGRI Focus Group Reducing Livestock Emissions from Cattle Farming. https://ec.europa.eu/eip/agriculture/sites/agri-eip/files/fgl8_ mp_feeding_strategies_2017_en.pdf (2017).

50. Iqbal, M. F., Cheng, Y.-F., Zhu, W.-Y. \& Zeshan, B. Mitigation of ruminant methane production: Current strategies, constraints and future options. World J. Microbiol. Biotechnol. 24, 2747-2755 (2008).

51. Ericksen, P. J. \& Crane, T. A. The feasibility of low emissions development interventions for the East African livestock sector: Lessons from Kenya and Ethiopia. ILRI Research Report 46 (2018).

52. Gerber, P. et al. Technical options for the mitigation of direct methane and nitrous oxide emissions from livestock: A review. Animal 7, 220-234 (2013).

53. Frater, P. Feed Additives in Ruminant Nutrition. Agriculture and Horticulture Development Board (AHDB). https://beefandlamb.ahdb.org.uk/wp-con- 
tent/uploads/2013/04/Feed-additives-in-ruminant-nutrition-FINAL.pdf (2014).

54. Meale, S. et al. Including essential oils in lactating dairy cow diets: Effects on methane emissions1. Anim. Prod. Sci. 54, 1215-1218 (2014).

55. Patra, A. K., Kamra, D. N. \& Agarwal, N. Effects of extracts of spices on rumen methanogenesis, enzyme activities and fermentation of feeds in vitro. J. Sci. Food Agri. 90, 511-520 (2010).

56. Yang, C., Rooke, J. A., Cabeza, I. \& Wallace, R. J. Nitrate and inhibition of ruminal methanogenesis: Microbial ecology, obstacles, and opportunities for lowering methane emissions from ruminant livestock. Front. Microbiol. 7, 132 (2016).

57. Durmic, Z. et al. In vitro screening of selected feed additives, plant essential oils and plant extracts for rumen methane mitigation. J. Sci. Food Agri. 94, 1191-1196 (2014).

58. Grainger, C. \& Beauchemin, K. Can enteric methane emissions from ruminants be lowered without lowering their production? Anim. Feed Sci. Technol. 166, 308-320 (2011).

59. Rasmussen, J. \& Harrison, A. The benefits of supplementary fat in feed rations for ruminants with particular focus on reducing levels of methane production. ISR N Vet. Sci. 2011 (2011).

60. Knapp, J., Laur, G., Vadas, P., Weiss, W. \& Tricarico, J. Invited review: Enteric methane in dairy cattle production: Quantifying the opportunities and impact of reducing emissions. J. Dairy Sci. 97, 3231-3261 (2014).

61. Knapp, D. \& Grummer, R. R. Response of lactating dairy cows to fat supplementation during heat stress. J. Dairy Sci. 74, 2573-2579 (1991).

62. EC. Ban on antibiotics as growth promoters in animal feed enters into effect. European Commission Regulation 1831/2003/EC. http://europa.eu/rapid/ press-release_IP-05-1687_en.htm (2005).

63. Assan, N. Possible impact and adaptation to climate change in livestock production in Southern Africa. IOSR J. Environ. Sci. Toxicol. Food Technol. 8, 104-112 (2014).

64. DEFRA. GB Bluetongue Virus Disease Control Strategy. Department for Environment, Food \& Rural Affairs, UK. https://assets.publishing.service. gov.uk/government/uploads/system/uploads/attachment_data/ file/343402/bluetongue-control-strategy-140727.pdf (2014).

65. Stevenson, C., Mahoney, R., Fisara, P., Strehlau, G. \& Reichel, M. The efficacy of formulations of triclabendazole and ivermectin in combination against liver fluke (Fasciola hepatica) and gastro-intestinal nematodes in cattle and sheep and sucking lice species in cattle. Aust. Vet. J. 80, 698-701 (2002).

66. HolsteinUK. Cow facts. UKCows.com. http://ukcows.com/holsteinUK/ publicweb/Education/HUK_Edu_DairyCows.aspx?cmh=66 (2018).

67. Hansen, P. 49th Florida DairyProduction Conference, Gainesville, 7pp. 
68. Gerber, P. J. et al. Tackling Climate Change Through Livestock: A Global Assessment of Emissions and Mitigation Opportunities (Food and Agriculture Organization of the United Nations (FAO), 2013).

69. Harvey, D. Powered by poo: Somerset dairy farm enjoys biogas boom. $B B C$ Online. https://www.bbc.co.uk/news/uk-england-somerset-35482839 (2016).

70. World Bank. Carbon credits serve up clean cooking options for West African Farmers. WorldBank.org. http://www.worldbank.org/en/news/feature $/ 2018 / 03 / 06 /$ carbon-credits-serve-up-clean-cooking-options-for-westafrican-farmers?CID=CCG_TT_climatechange_EN_EXT (2018).

Open Access This chapter is licensed under the terms of the Creative Commons Attribution 4.0 International License (http://creativecommons.org/licenses/ by $/ 4.0 /$ ), which permits use, sharing, adaptation, distribution and reproduction in any medium or format, as long as you give appropriate credit to the original author(s) and the source, provide a link to the Creative Commons licence and indicate if changes were made.

The images or other third party material in this chapter are included in the chapter's Creative Commons licence, unless indicated otherwise in a credit line to the material. If material is not included in the chapter's Creative Commons licence and your intended use is not permitted by statutory regulation or exceeds the permitted use, you will need to obtain permission directly from the copyright holder.

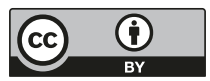

